\title{
The Cultivation of Sweet Pepper (Capsicum Annuum) in Foumbot Agricultural Area, West Region, Cameroon
}

\author{
Onguene Dieudonne*, Nguefack Julienne, Joseph Blaise Dongmo Lekagne, Charles Dakole Daboy, \\ Azah Udom Rene, Ndonkeu Mangoumou Ghislaine \\ Department of Biochemistry, University of Yaounde I, Yaounde Cameroon \\ "Corresponding author email: onguened@gmail.com
}

Received: 30 October 2020 / Revised: 03 February 2021 / Accepted: 16 March 2021 / Published: 22 March 2021

\begin{abstract}
ABS TRACT
This study aimed to get information on the cultivation of sweet pepper from the North West Region of Cameroon (Foumbot). Data for the study were obtained from 92 farmers with the aid of wellstructured questionnaires. Results obtained showed that among the sweet pepper farmers, males represented $80 \%$ of the sampled population and women $12 \%$, all of them aged between 18 to 48 years old. Their level of education varies from primary school to University with the majority found between primary school $(48 \%)$ and secondary school $(30 \%)$. 41\% of the sampled cultivators have the greatest level of experience in between 10 to 30 years and $52 \%$ with the lowest level of experience varying from 1 to 10 years. The sweetest pepper varieties cultivated was Yolo wonder and Simba. $89 \%$ of respondents had a sweet pepper field with a surface area between 0.5 and 1 hectare. According to farmers, the nursery is usually attacked by fungi after one week of growth, which always cause stems rot. Fungicides (Mancostar 80WP) and insecticides (Mocap EC, Timik, Plantineb 80WP, Jumper and Ascot) are the most chemical products used to treat stems rot. Cypermethrin and Mancozeb represent respectively $63 \%$ and $85 \%$ of active ingredients used by the sampled growers to fight against sweet pepper diseases. $46 \%$ of the sampled farmers said that they prefer spray pesticides in all stages while $44 \%$ of sweet pepper farmers did not take note of the number of times, they applied chemicals pesticides on their crops. NPK: 20.10 .10 is the most chemical fertilizer used to grow sweet pepper. The major diseases and pests encountered in that region are (1) diseases: Mildew, cercospora leaf spot, phytophthora blight, fusarium wilt, anthracnose, ripe rot, tobacco mosaic virus, cucumber mosaic virus, and gal formations; (2) pests: flee beetles, cutworms, aphids, vegetable weevil, caterpillars, grasshoppers, pepper maggots and leaf miners.
\end{abstract}

Keywords: sweet pepper farming, pest and diseases management, chemical usage, Foumbot

\section{Introduction}

In Cameroon in general and in the Foumbot agricultural area in particular, synthetic pesticides have been widely overused by farmers (Galani et al., 2020, Sonchieu et al., 2017; Tandi et al., 2014,). In this area, vegetables are the most produced foods alongside maize and beans. They are produced throughout the year and have grammatically contributed to food security in the zone (Houjayfa et al., 2020, Mfopouet al., 2017) The main vegetable crops cultivated are green beans (Phaseolus vulgaris L.), sweet pepper (Capsicum annum L.), watermelon (Citrillus lanatus L.), leeks (Allium porrum L.), tomato, lettuce (Lactucasativa L.), amaranth (Amaranthus cruentus L.), huckleberry (Solanum scabrum Mill.), carrot (Daucus carota L.), pepper (Capsicum frutenscens L.), cabbage (Brassica oleraceae var. capitata L.) and traditional vegetables. (Joseph et al., 2020, Sonchieu et al., 2018 ; Tabe-Ojong et al., 2017). Vegetables are a source of micronutrients and important source of proteins, minerals, vitamins, and amino acids (Lal et al., 2020, Tata et al., 2016Asongwe et al., 2014 ;). In Cameroon, commonly grown exotic vegetables include tomato (Lycopersicon esculentum), onion (Allium cepa), cabbage (Brassica oleracea) and sweet pepper (Capsicum annum), (Njume et al., 2020, Jean et al., 
2019, Asongwe et al., 2014; Tata et al., 2016). Most of these vegetables are grown all year-round with two to four rotations per year (Asongwe et al., 2014). Among the above vegetable, sweet pepper (Capsicum annum L. ssp. annuиm) is a thermophile vegetable species, which worldwide produces over 26 million tons of fruits (FAOSTAT., 2014). Pepper fruits are an important source of antioxidants, such as ascorbic acid, carotenoids, tocopherols (Guilherme et al., 2020; Fratianni et al., 2020, Sreeramulu et al., 2010), phenolic compounds, particularly flavonoids (Fratianni et al., 2020, Chen et al., 2013); also, their flavour and nutritional value are affected by organic acids and sugars (Kaur et al., 2020; Guilherme et al., 2020; Luning et al., 1994). Notably, polyphenols and flavonoids have been recently in high regard for evaluating pepper fruit value (Kaur et al., 2020; Fratianni et al., 2020; Luning et al., 1994), as they protect the human organism cells against the oxidation caused by free radicals (Caruso et al.,2019; Caruso et al., 2018 ;). Indeed, they have shown beneficial bioactivities to human health, such as reducing the risk of cancer, heart diseases, diabetes (de Sá et al., 2020; Deepa et al., 2007) and, notably, their antioxidant activity depends on their hydroxyl groups number and arrangement (Guilherme et al., 2020; Grajeda-Iglesias et al., 216; Zhuang et al., 2012).

However, pepper occupies a good rank among diversification crops for agricultural exports in Cameroon (Genang et al., 2020; Dzokou et al., 2020; Segnou et al., 2012). Prices are more and more attractive all year round, particularly for out of season production. The crop, therefore, offers to small Cameroonian's farmers specialized in this horticultural branch interesting incomes, thereby increasing their living standards (Genang et al., 2020; Dzokou et al., 2020; Segnou et al., 2012). Despite the importance of pepper, unfortunately in the field, pepper is among the most infested crops, mostly during rainy seasons (March to October), (Arogundade et al., 2020; Dzokou et al., 2020; Segnou et al., 2012). In Cameroon, different agricultural investigations have revealed that this crop is facing a certain number of major constraints such as fungi; bacterial and viral diseases. These constraints are present in all pepper commercial production zones in Cameroon and are responsible for significant marketable fruit yield losses (Dzokou et al., 2020; Segnou et al., 2012).

This study was undertaken to determine the cultivation of sweet pepper in Founbot. The specific aim is to: (1) determine the most varieties of sweet pepper that is grown in Foumbot and small tools that are used to grow sweet pepper, (2) describe the method that is used to grow seedlings and their transplantation, (3) evaluating the types of insecticides and fungicides used by farmers in the said area, (4) present the major sweet pepper diseases in that region of Cameroon and (5) determine farmers' means in pest and disease management.

\section{Methodology}

\subsection{Study site}

Foumbot is a sub-division situated in the Division of the West Region of Cameroon. Its geographical coordinates fall under $5^{\circ} 16^{\prime}$ to $5^{\circ} 35^{\prime} \mathrm{N}$; $10^{\circ} 30^{\prime}$ to $10^{\circ} 45^{\prime} \mathrm{E}$; $1100-1300$ masl with $120 \mathrm{~m}$ (390 ft) elevation for a total surface area of $579 \mathrm{Km}^{2}$. The annual rainfall varies between 2500 and $5000 \mathrm{~mm}$ (Sonchieu et al 2018). There are two seasons: the rainy season which runs from mid-March to mid-November and the dry season which takes place between mid-November and mid-March. The population that is mainly farmers is estimated at 90,406 inhabitants. More than half of the people live in a rural area where farming is the main activity. Ethnic groups in Foumbot are the Bamoun's, Bamiléké's, Banso's and Mbororo's. Foumbot is a major sweet pepper and other vegetables growing zone in Cameroon (Sonchieu et al 2018; Tarla et al., 2015). For this work, the following villages were visited: Fossang, Kouffen and Soukpen.

\subsection{Data Collection}

A total number of 110 farmers were interviewed using a pretest questionnaire and 92 farmers were finally selected to be part of the sampling population. They were interviewed from the 5th May 2020 to the 5th June 2020. The following criteria were used to select the sample: hold a farm of sweet pepper; having 
Onguene Dieudonne et al., Adv. J Social Sci.; Vol. 8, Issue 1, pp: 54-66, 2021

cultivating sweet pepper for at least one year. After selection, 46 questionnaires were administered to them. The questionnaire was made up of open and closed questions based on identification data, seeds and tools, work practices, and experiences.

\subsection{Statistical analysis}

Data from the survey were manually codified, computerized and processed using Excel software 10.0. Statistical data analysis was performed using the package SPSS 16.0 software. A descriptive statistical analysis was done to generate frequencies.

\section{Results}

\subsection{Characteristics of the Studied Famers}

Figures:1, 2, 3 and 4 below illustrate respectively information concerning women and men level of education, the percentage of men and women sweet pepper farmers, the ages of sweet pepper cultivators and their year of experience. Males represented $80 \%$ of the sampled population. Their level of education varies from primary school to University with the majority found between primary school (48\%) and secondary school $(30 \%)$. On the other hand, females represent 12 per cent of the sampled farmers and their level of education fluctuated from primary $(6 \%)$ and secondary $(6 \%)$ school. However, most sweet pepper farmers $(80 \%)$ aged between 18 to 48 years old. The years of experience given by farmers vary from one to thirty years with $48 \%$ who have the greatest level of experience in between 10 to 30 years and $52 \%$ with the lowest level of experience varying from 1 to 10 years. Most of them produced sweet pepper for market and few produced for both the market and home consumption.

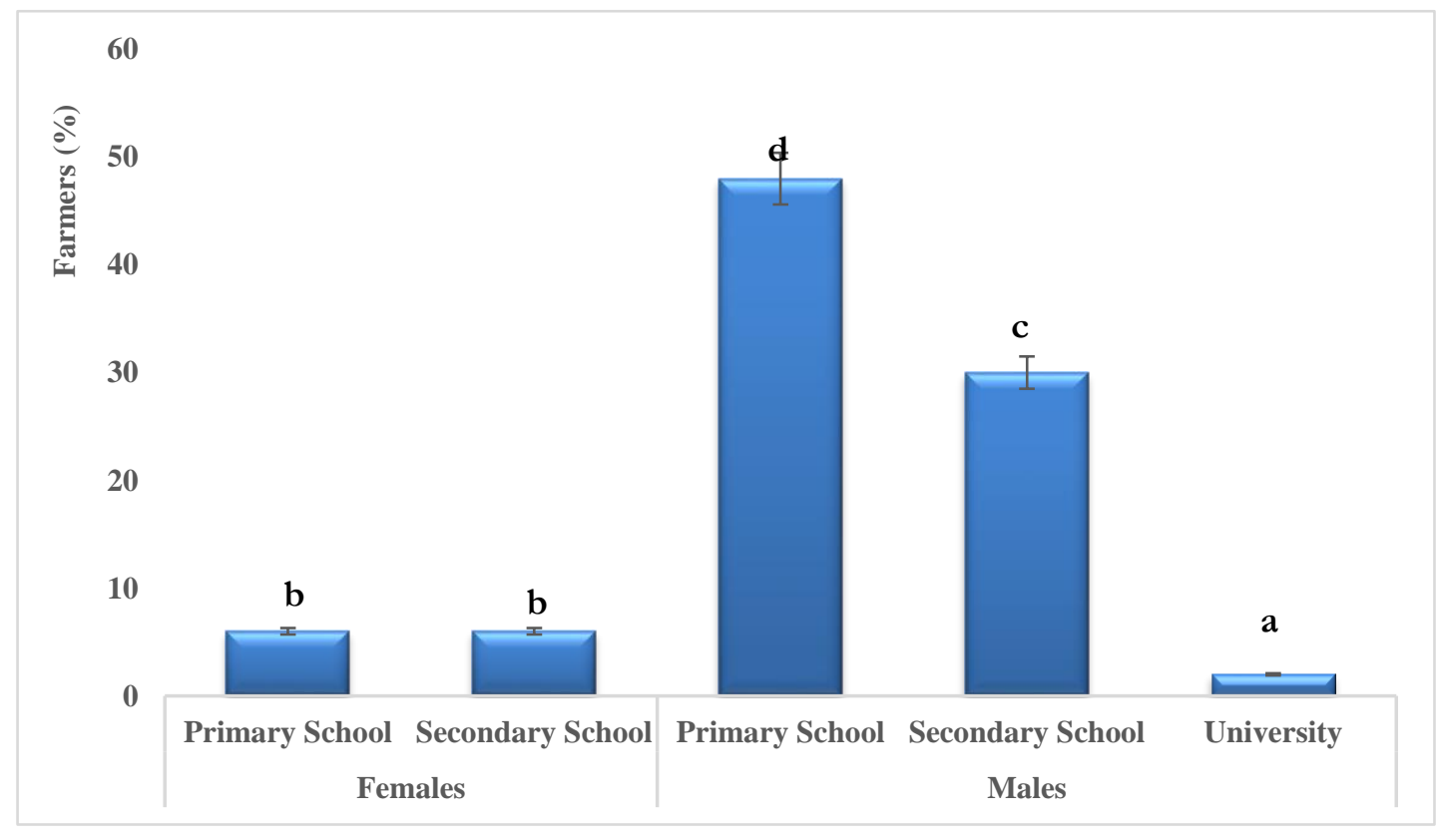

Figure 1: Women and men level of education 


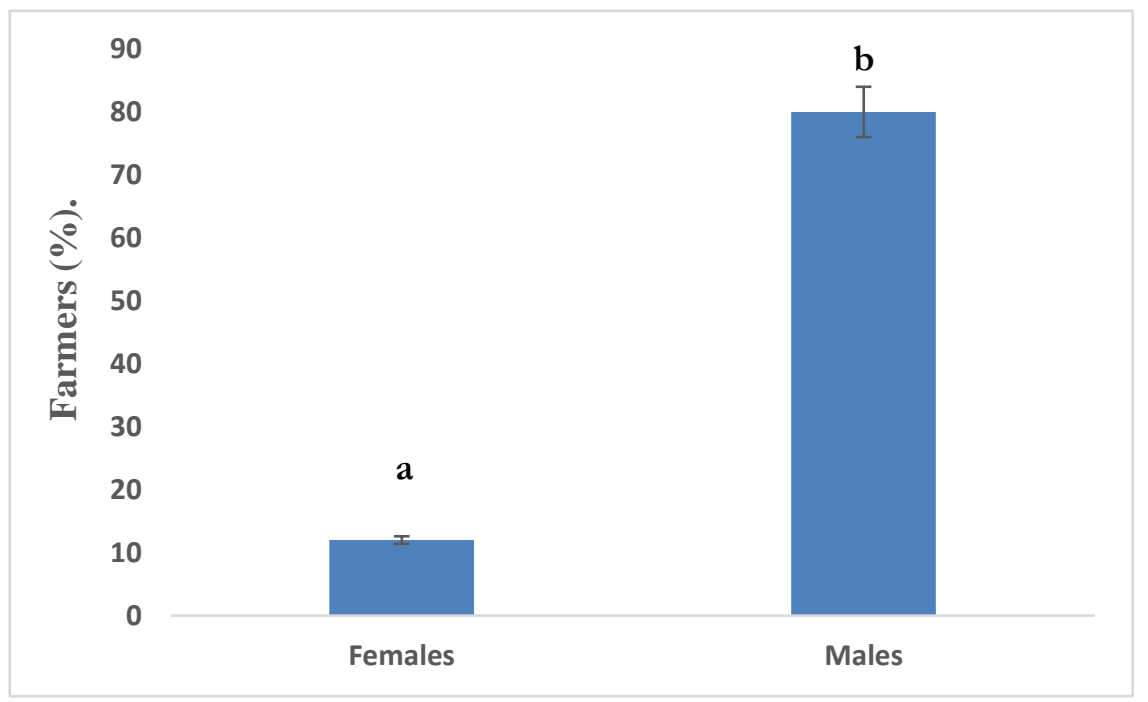

Figure 2: The percentage of men and women sweet pepper farmers

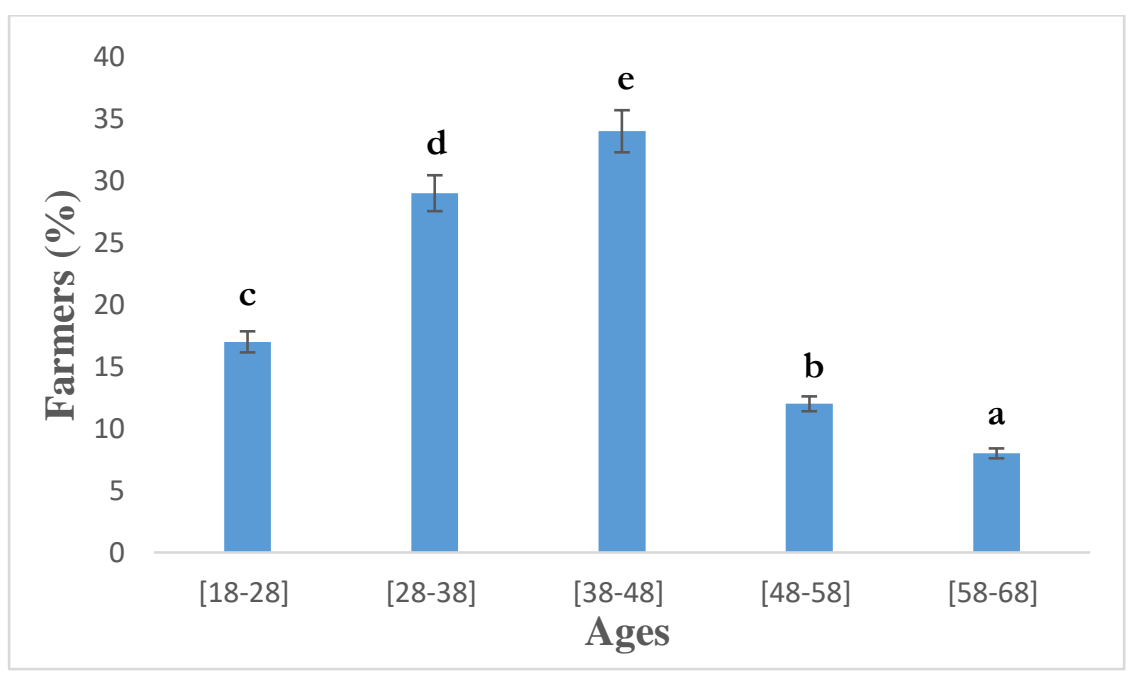

Figure 3: The ages of sweet pepper cultivators

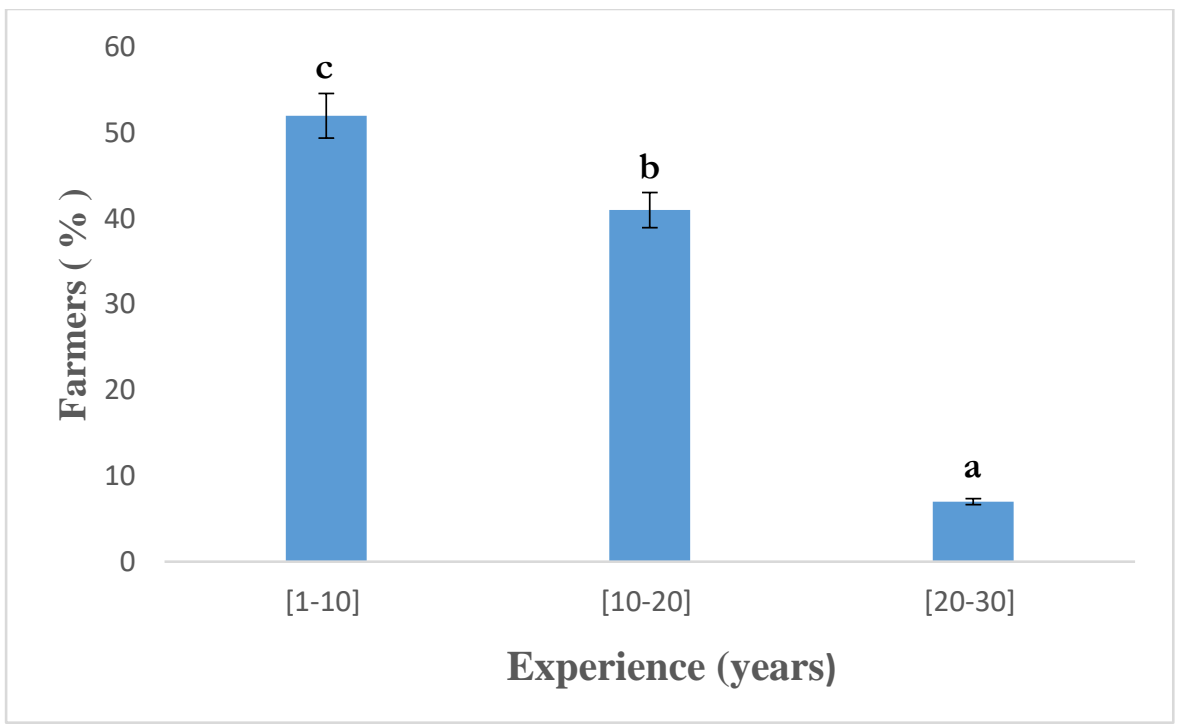

Figure 4: Experience of sweet pepper growers 
Onguene Dieudonne et al., Adv. J Social Sci.; Vol. 8, Issue 1, pp: 54-66, 2021

\subsection{Varieties of sweet pepper seeds and small tools that are used to grow sweet pepper}

\subsubsection{Varieties of sweet pepper seeds}

The varieties of sweet pepper seeds cultivated in Foumbote by the sampled cultivators are Yolo wonder, Simba, Poivron vert Lamuyo F1. But Yolo wonder and Simba varieties are the most used. Those varieties are gotten by the sweet pepper cultivators from the distributors of phytosanitary products.

\subsubsection{Small tools used by sweet pepper farmers}

Table 1 presents the small tools used by most of the sweet pepper farmers from the West Region of Cameroon (Foumbot Agricultural Area).

Table 1: Small tools used by sweet peppers farmers and their utilization

\begin{tabular}{|c|c|}
\hline Tools & Usage \\
\hline Machete & Clearing Brush \\
\hline Rakes & Smooth out beds and Collecting Leaves \\
\hline Hoe & Eliminate weeds \\
\hline Shovel & $\begin{array}{l}\text { Used respectively to dig large holes and transport } \\
\text { heavier materials such as wet soil and cut the roots and } \\
\text { sods as well as break up compacted soil. }\end{array}$ \\
\hline Forks & $\begin{array}{l}\text { Used for digging of soils in situations where the use of } \\
\text { spade may be difficult for turning of soils, to till large } \\
\text { areas of soil, break up compacted clods and rake out } \\
\text { weeds. }\end{array}$ \\
\hline Glove & $\begin{array}{l}\text { Used to protect hands and fingers from cuts, blisters, } \\
\text { calluses, sun damages, abrasions and dirt. }\end{array}$ \\
\hline Footwear & Used to protect feet from stones, falling items or tools \\
\hline Wheelbarrow & $\begin{array}{l}\text { Used for transportation of seedlings, planting materials, } \\
\text { growing media as well as other small loads. }\end{array}$ \\
\hline Meter & To measure the distance in between seedlings and rows \\
\hline Watering can & $\begin{array}{l}\text { It is used for watering seedbeds, nursery beds and potted } \\
\text { plants to avoid washing off the soil and causing damage } \\
\text { to young seedlings. }\end{array}$ \\
\hline Hand Pressure Agricultural Sprayer & $\begin{array}{l}\text { It is used for spraying insecticides, fungicides, } \\
\text { herbicides, }\end{array}$ \\
\hline Motopomp & To water sweet pepper plants \\
\hline
\end{tabular}

\subsection{Sweet pepper cultivation}

\subsubsection{Field for sweet pepper cultivation}

Most farmers (89 \%) had a sweet pepper field with a surface area between 0.5 and 1 hectare while only a few farmers ( $7 \%$ ) had sweet pepper field of about 2 hectares (figure 5). Men (35\% and 38\%) respectively grow sweet pepper in the area of 0.5 ha and 1 ha and only 7 per cent of men use 2 ha. On the other hand, $8 \%$ of women out of $12 \%$ generally use 0.5 ha to cultivate sweet pepper. 


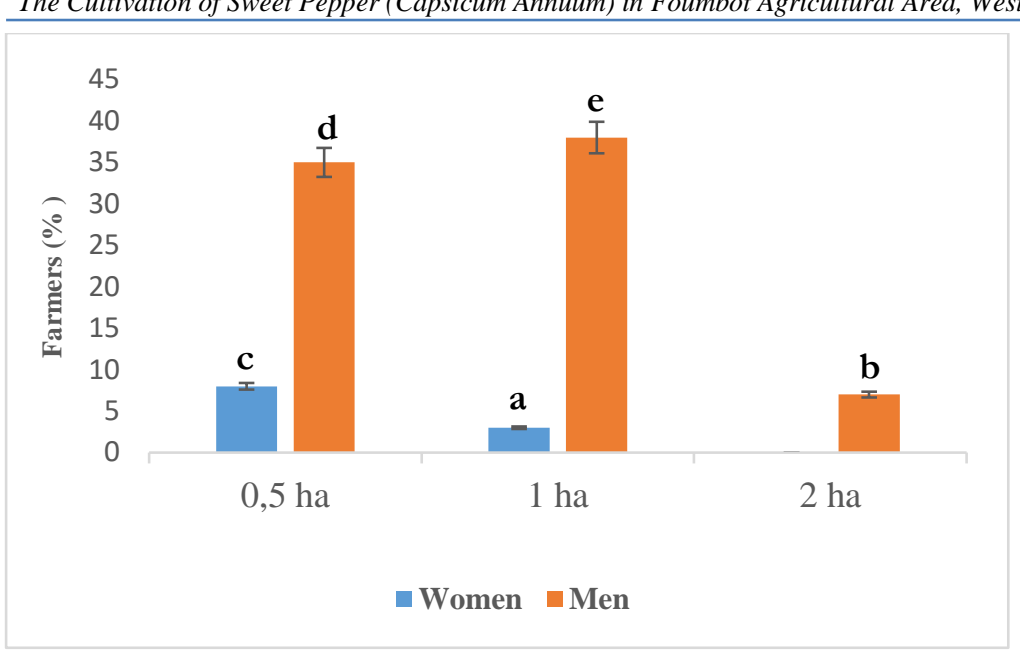

Figure 5: Farm size distribution used for sweet pepper production

\subsubsection{Seedling, cultivation, and transplantation}

$80 \%$ of sweet pepper farmers that was interviewed from the West Region of Cameroon usually grow sweet pepper two times per year. $79 \%$ grow the nursery on ridges and $21 \%$ of the remaining farmers on the seedbeds. The location of the nursery is generally either far from the site of transplantation or near depending on the availability of water. In that region of Cameroon, most of the farmers cultivate sweet pepper throughout the year. Those who are not able to get the motopomp or pumps to water plant from long distancings only grow sweet pepper during the raining season. However, seeds are not treated before being sown but only one week after sowing. Sweet pepper seeds are sown in nursery beds after enriching it with the mixture of cow dung and let it during one week. Usually, after one week of growth, the nursery is attacked by fungi, which always cause stems rot. The pesticides used to treat nursery by sweet pepper farmers in that region are respectively fungicide (Mancostar 80WP) and insecticides (Mocap EC, Timik, Plantineb 80WP, Jumper and Ascot). The frequency of the nursery treatment was after one week or two, depending on each farmer, still the right time of seedlings transplantation. Seedlings are transplanted after a month and a half of growth. Farmers generally transplant seedlings on ridges, which are a mixture of the soil and cow dung. Then, after one week of transplantation farmers enrich the soil with chemical fertilizers such as NPK: 20.10.10, which is the most synthetic fertilizer used for sweet pepper cultivation, including NPK: 30.10.10, which is, on the other hand, the most foliar fertilizer used. Generally, they fertilize the soil that surrounds one or two plants of sweet pepper with a handful hand of synthetic fertilizer. The below table 2 presents the frequencies of soil amendment that are usually applied by the surveyed cultivators.

Table 2: Frequency of chemical fertilizers application

\begin{tabular}{|l|l|}
\hline Frequencies & Sweet pepper farmers \\
\hline Three times & $3 \%$ \\
\hline One week after transplanting & $2 \%$ \\
\hline Three weeks after transplanting & $3 \%$ \\
\hline After two weeks of transplanting and during the first flowering & $6 \%$ \\
\hline Two weeks after transplanting and after each harvesting & $32 \%$ \\
\hline After each 21days and each harvesting & $48 \%$ \\
\hline Three times before harvesting and after two harvestings & $6 \%$ \\
\hline
\end{tabular}

After the transplantation of sweet pepper seeds 13 percent of farmers usually sow other plants around or inside the farm of sweet pepper such as beans, corn and cucumber. 
Onguene Dieudonne et al., Adv. J Social Sci.; Vol. 8, Issue 1, pp: 54-66, 2021

\subsubsection{Water used for irrigation in sweet pepper farming and the choice of growing}

The surface canals are the principal means of supplying water to the farms. The irrigation water used by the sampled farmers in Foumbot agricultural area has multiple origins such as water coming out of the mountains, streams, swamp and rainwater. Most sweet pepper farms are not located far from those origins of water. Besides, the main tools used by sweet peppers growers, who had larger surfaces $(>0.25 \mathrm{ha})$, to water sweet pepper plants are motopomp/pumps and watering can for those that had fewer surfaces. Generally, the majority of sweet pepper cultivators prefer growing sweet pepper during the rainy season and only a few of them prefer the dry season.

\subsubsection{Sweet pepper diseases and disease management}

According to the respondents, sweet pepper diseases start appearing after one week of transplantation and they mainly attack either leaves, stems, and fruits or the whole plant depending on the type of diseases. To fight against those diseases the cultivators of sweet peppers always use the types of pesticides presented in table 3.

Table 3: Types of pesticides and herbicides used by the cultivators of sweet pepper.

\begin{tabular}{|c|c|c|c|}
\hline Class & Commercial names & Active ingredient & $\begin{array}{l}\text { Toxicity } \\
\text { class }\end{array}$ \\
\hline \multirow{10}{*}{ Insecticide } & Cypercal 50 EC & Cypermethrin & II \\
\hline & Cigogne $50 \mathrm{EC}$ & Cypermethrin & II \\
\hline & Plantineb 80WP & Mabeb & III \\
\hline & Cyperplant $100 \mathrm{EC}$ & Cypermethrin & II \\
\hline & Cytrine $25 \mathrm{EC}$ & Cypermethrin & II \\
\hline & Ascot & Lambda-cyhalothrine & II \\
\hline & Fix 50 & & II \\
\hline & Timik & Aldicarb & \\
\hline & K-Optimal & Lambda-cyhalothrine + Acétamipride & II \\
\hline & Mocap EC & Ethoprop & \\
\hline \multirow{7}{*}{ Fungicides } & Mancoxy plus $720 \mathrm{WP}$ & Metalaxyl + Mancozeb & III \\
\hline & Cleanzeb Blue 80WP & Mancozeb & III \\
\hline & Penncozeb 80WP & Mancozeb & III \\
\hline & Fongistar $72 \% \mathrm{WP}$ & Metalaxyl + Mancozeb & III \\
\hline & Mancostar 80WP & Mancozeb & III \\
\hline & Manco 80WP & Mancozeb & III \\
\hline & Trimangol 80WP & Maneb & III \\
\hline \multirow[t]{4}{*}{ Herbicides } & Roundup & Glyphosate & III \\
\hline & Suprazone Royal & Paraquat & II \\
\hline & Amistar $720 \mathrm{SL}$ & 2,4-D Sel Amide & III \\
\hline & Casse-tout & Glyphosate & III \\
\hline
\end{tabular}

Toxicity class according to WHO: III = slightly hazardous, II = moderately hazardous 
The Cultivation of Sweet Pepper (Capsicum Annuum) in Foumbot Agricultural Area, West Region, Cameroon

Those diseases usually cause more than $50 \%$ yield losses, which reduces agricultural yields. $85 \%$ of the respondents were not able to identify sweet pepper pests and diseases. They did not have access to information about integrated pest management, pesticide use and safety, or insect and disease identification. The vegetable growers depend on the experience of others for advice on managing pests and diseases. However, the major symptoms described by the sweet pepper farmers and that have also been observed from sweet pepper farms in Foumbot are:

$>$ Circular lesions on leaves and stems with dark margins,

$>$ mosaic-like patches (mottling) on the leaves, curling of leaves and the yellowing of plant tissues.

$>$ mosaic blight, ringspot, fruit woodiness and necrosis of fruit.

$>$ the formation of small, circular, water-soaked spots on leaves, stems, petioles,

$>$ Yellowing of foliage and wilting upper leaves; wilting spread to all parts of a plant; leaves remain attached to plant and are dark green; red-brown discolouration of vascular tissue; plant death,

$>$ yellow to brown discolouration of the upper leaf; edges of leaves; the dropping of leaves from a plant,

$>$ plants becoming stunted and lower leaves turning yellow; as the infection progresses, more leaves turn yellow and begin dropping from the plant; plants wilt during the day and recover at night; wilting becomes permanent and plant death ensues.

D Black lesions on stems; wilting plant; circular grey-brown lesions on leaves; dark lesions on fruit,

$>$ Small soft bodied insects on the underside of leaves and/or stems of a plant; usually green or yellow in colour, yellow leaves and distorted, necrotic spots on leaves and/or stunted shoots.

\subsubsection{Pesticides Used to cultivate sweet pepper}

About $85 \%$ of farmers interviewed used synthetic pesticides. The reasons provided by the $15 \%$ not using pesticides were high prices, especially for small-scale farmers that did not produce a lot of sweet peppers. Pesticides used include fungicides, herbicides and insecticides. The characteristics of synthetic pesticides used are presented in Table 3. Respectively 10 insecticides, 07 fungicides and 05 herbicides are used by sampled farmers as pesticides, according to these statistics. Among the class of insecticides, cypermethrin represents $63 \%$ of active ingredients compared to lamda-cyalothrin, Aldicarb and others. On the other hand, Mancozeb represents $85 \%$ of active ingredients, among the class of fungicide, compared to Maneb. The toxicity of those pesticides varies from class II (moderately toxic) to class III (slightly hazardous). Most of the sampled farmers abundantly use two fungicides (maneb and mancozeb) that are used in all combinations $(100 \%)$, which are all classified as slightly hazardous substances according to WHO (1965 and 2004) toxicity classification. Concerning herbicides utilization, only three were reported, to be used by the farmers that were sampled, among which glyphosate (the first) is used at $50 \%$ followed by paraquat at $37 \%$ (the second) and 2.4- D 23\%. For all pesticides, users can vary the type of mixtures but the contents remain the same with changes in concentration. However, the frequency of spraying those pesticides (fungicides and insecticides), by the sampled farmers, to treat sweet pepper diseases is after each week and depends on the degree of the disease. Also, while spraying pesticides, the whole sweet pepper plant is treated instead of one part such as leaves stems and fruit. Herbicides can be used two or three times per crop cycle or for a different field.

\subsubsection{The stage of pesticide application}

The stage of pesticide application varied with sweet pepper growth stages (Figure 6). The majority of the cultivators of sweet pepper could not say what time of plant growth was most effective for controlling pests. That is the reason why $46 \%$ of the sampled farmers said that they prefer spray pesticides in all stages. However, a weekly pesticide spraying was the most common, with most of the sampled farmers spraying insecticide and fungicides, respectively. $44 \%$ of sweet pepper farmers did not take note of the number of times they applied chemicals pesticides on their crops. 


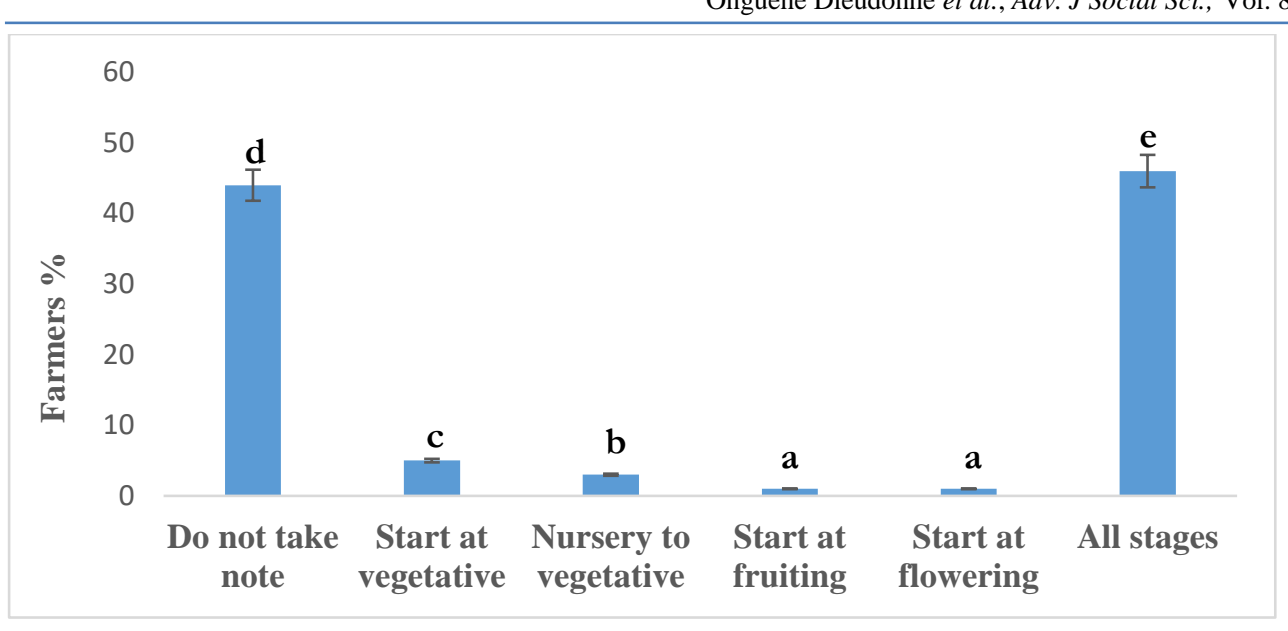

Figure 6: Pesticide application periods.

\subsubsection{The harvesting of sweet pepper fruits}

86 percent of the sampled farmers harvest 0.5 to 20 tons of sweet pepper fruit per farm. Only 5 percent and 3 percent respectively harvest 20 to 50 tons and 50 to 100 tons of sweet pepper fruit per farm. (Figure: 7). However, most of them harvest more than three times. They usually harvest fruit after one to seven days of the last spraying of pesticides and most farmers do not use synthetic products to extend the period of sweet pepper fruit conservation. Besides, after harvesting, the period of the conservation of sweet pepper fruit varies in between seven to fifteen days.

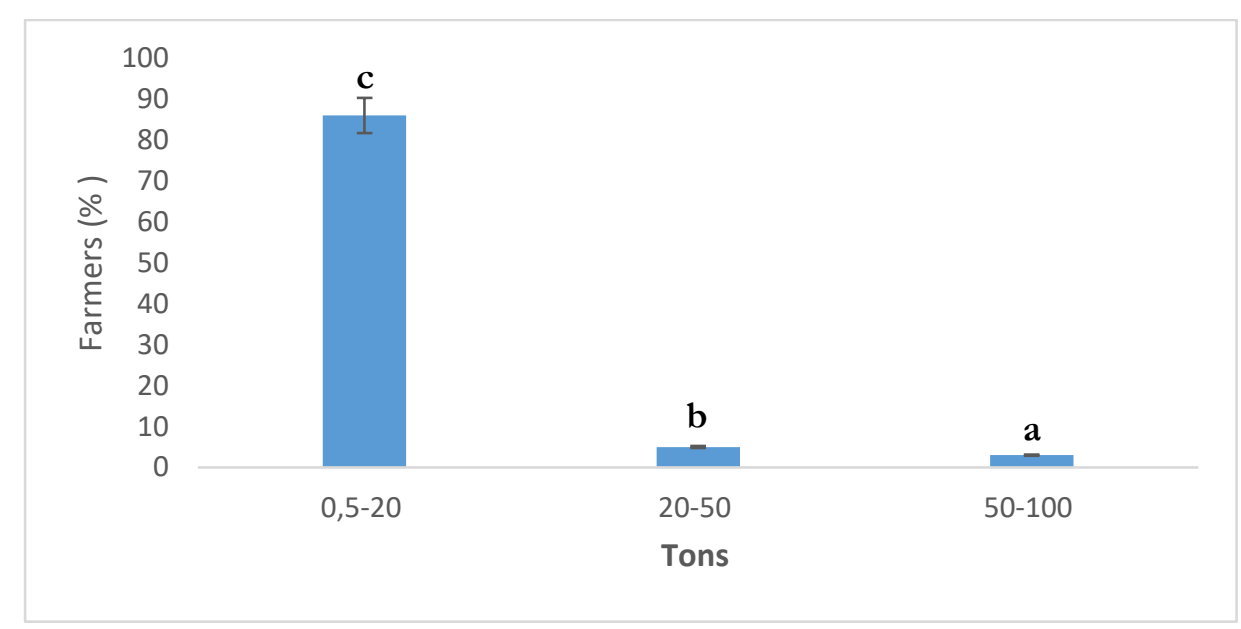

Figure 7: the number of sweet pepper tons produced by the sampled cultivators

\section{Discussion}

From the survey, the data showed that farmers from the West Region of Cameroon (Foumbot) are not of equal proportion of men and women. The same finding was also observed by (Siri et al., 2020; Nguemo et al., 2019), including (Fonjong et al., 2020) who also noticed that the percentage of men and women farmer was not equal. This was not the case of (Mfopou et al., 2017) in the centre region of Cameroon (Yaounde) where the percentage of men was equal of those of women. The different observed between men and women farmers from the West Region of Cameroon may be due to the lack of women dynamism who do not generally conduct their activities out of their homes. Sweet pepper farming is mostly done at Foumbot by the farmers age between 18 to 48 years old, which is an indicator of the robustness of the activity. This age group of sweet pepper growers was also observed by (Mbangari et al., 2020; Sonchieu et al., 2018). The greatest level of experience (10 to 30 years) observed from the sampled farmers might confirm that the west region of Cameroon (Foumbot) is the first region of sweet pepper cultivation. The study run by (Tarla et al., 2015) also found that Foumbot is the major vegetable growing such as sweet pepper and tomatoes. 
The Cultivation of Sweet Pepper (Capsicum Annuum) in Foumbot Agricultural Area, West Region, Cameroon

The most varieties of sweet pepper seeds cultivated in Foumbot are Yelo wonder (55\% of the surveyed farmers) and Simba (45\% of the surveyed farmers). This could be because, according to our survey, the Yelo wonder variety is not expensive than the Simba variety which on the other hand is expensive and resists to many diseases.

Diseases and pests are important constraints to sweet pepper production in the west region of Cameroon (Nguemo et al., 2019). This could lead to the abundant utilization of chemical products. The abundant usage of the above active ingredients by the sampled growers testifies to the favourable environment for sweet pepper plant diseases development and their effectiveness. The huge abundant of those diseases during the cultivation of sweet pepper might be because sweet pepper seeds are not treated before being sown but only one week after sowing. It could also be explained by the fact that the same molecules of the above synthetic pesticides have been used since decades in various mixtures or commercial names in which concentrations are often modified or set as a combination of more than one active molecule (Sonchieu $e t$ al., 2018). It has been reported from the same area of Cameroon that, the choice of a pesticide depends on the availability instead of the specificity of a crop pathogen. The survey done by (Sonchieu et al., 2018) also showed that the misuse of pesticide applicators in Foumbot agricultural area, lead with the increasing of vegetable diseases and resistance mechanisms in pathogens. In 2020, Lengai et al also found that the utilization of pesticides leads with the resistance mechanisms in pathogens. In addition, the persistence of those diseases might be because most of the sampled cultivators did not either finish the secondary school or attain the university level and do not have technical assistance from trained technicians for them to overcome sweet pepper diseases. (FAOSTAT., 2014; Pouokam et al., 2017).

The most commonly used chemical products were respectively, insecticides (Lambda-cyhalothrine + Acétamipride and Cypermethrine), and fungicides (Metalaxyl and Mncozeb), (Fai et al., 2019; Nguemo et al., 2019; Matthews et al., 2003). Pouokam et al., 2017 reported on the use of these classes of chemicals. However, the number of pesticides listed could be evidence of serious pest problems and difficulties in control, which prompt growers to try several formulations; it might also be an indication that sweet pepper farmers are not using appropriate pesticides (Fai et al., 2019; Nguemo et al., 2019). In addition, application means such as target plant part, time, frequency and doses could be incorrect due to the lack of knowledges (Nguemo et al., 2019). Another reason may be pest resistance to pesticides or the lack of means to purchase pesticides is the highest evidence of pest and disease outbreaks (Tabashnik et al., 2014; Abang et al., 2013). According to our survey, most sweet pepper cultivators prefer growing sweet pepper during the rainy season than the dry season. The reasons behind the choice of growing season could be because during the rainy season, water is available and insect pests are reduced. During the dry season, diseases are not serious and cost of sweet pepper production is lower.

The different frequencies of soil amendment and pesticides used obtained in this study might be led to the lack of training concerning the cultivation of sweet pepper and the level of education of the respondents (Nguemo et al., 2019). However, according to the described and observed symptoms of sweet pepper diseases, the major diseases and pests that lead with the cultivation of sweet pepper in Foumbot are (1) diseases: Mildew, cercospora leaf spot, phytopthora blight, fusarium wilt, anthracnose, ripe rot, tobacco mosaic virus, cucumber mosaic virus, and gal formations; (2) pests: flee beetles, cutworms, aphids, vegetable weevil, caterpillars, grasshoppers, pepper maggots and leaf miners. The same major diseases and pests had also been reported by (Lin et al., 2020; Amuoh, C. N, 2011). The few numbers of tons harvested by sweet pepper cultivators from the West Region of Cameroon (Foumbot) could be led to the above diseases and the lack of farmers' means respectively in soil amendment, pest and disease management.

\section{Conclusion}

This study demonstrates that sweet pepper production is a year-round activity in the west region of Cameroon. Pests and diseases are important constraints to sweet pepper production, which lead to a great loss of yield. The lack of Knowledge respectively in diseases management, pest management and pesticides application constitute a major obstacle in sweet pepper production systems. Indeed, Introduction of 
Onguene Dieudonne et al., Adv. J Social Sci.; Vol. 8, Issue 1, pp: 54-66, 2021

training programs for sweet pepper farmers on identification and management of pests and safe use of pesticides is necessary. This might increase farmer knowledge of sweet pepper diseases and pests and improve management practices, especially with the high illiteracy level among farmers. However, an alternative educational program such as the combined utilization of organic fertilizers and biopesticides are also necessary for farmers in general and specifically, sweet pepper farmers to overcome vegetable diseases without having to face financial issues and destroying the environment.

\section{Declarations}

\subsection{Acknowledgements}

The authors thank Mfondi Ibrahim for his assistance during the period of the survey.

\subsection{Informed Consent}

Before starting to run this survey, all the surveyed farmers gave a verbal consentment which allowed us to publish the result of this article without any conflict. The data presented in this survey article did not include data collected from human and animal samples. All the results of this survey came from the data collected from the observations done throughout sweet pepper farmers and the answers of 46 questionnaires.

\subsection{Competing Interests}

The authors declared that no conflict of interest exist in the publication of this work.

\subsection{Publisher's Note}

AIJR remains neutral with regard to jurisdictional claims in published maps and institutional affiliations.

\section{How to Cite this Article:}

Dieudonne, O., Nguefack, J., Dongmo Lekagne, J. B., Dakole Daboy, C., Azah Udom, R., \& Ndonkeu Mangoumou, G. (2021). The Cultivation of Sweet Pepper (Capsicum Annuum) in Foumbot Agricultural Area, West Region, Cameroon. Advanced Journal of Social Science, 8(1), 54-66. https://doi.org/10.21467/ajss.8.1.54-66

\section{References}

Abang, A. F., Kouame, C. M., Abang, M., Hannah, R., \& Fotso, A. K. (2013). Vegetable grower's perception of pesticide use practices, cost, and health effects in the tropical region of Cameroon. International Journal of Agronomy and Plant Production, 4(5), 873-883. http://www.ijappjournal.com

Asongwe, G. A., Yerima, B. P., \& Tening, A. S. (2014). Vegetable production and the livelihood of farmers in Bamenda Municipality, Cameroon. International Journal of current microbiology and applied sciences, 3(12), 682-700. http://www.ijcmas.com

Arogundade, O., Ajose, T., Osijo, I., Onyeanusi, H., Matthew, J., \& Aliyu, T. H. (2020). Management of Viruses and Viral Diseases of Pepper (Capsicum spp.) in Africa. In Capsicum. IntechOpen.

Caruso, G., Stoleru, V. V., Munteanu, N. C., Sellitto, V. M., Teliban, G. C., Burducea, M., Butnariu, M. (2018). Quality Performances of Sweet Pepper under Farming Management. Notulae Botanicae Horti Agrobotanici Cluj-Napoca, 47(2), 458-464. DOI: https://doi.org/10.15835/nbha47111351

Caruso, G., Stoleru, V. V., Munteanu, N. C., Sellitto, V. M., Teliban, G. C., Burducea, M., \& Butnariu, M. (2019). Quality performances of sweet pepper under farming management. Notulae Botanicae Horti Agrobotanici Cluj-Napoca, 47(2), 458-464. https://doi.org/10.15835/nbha47111351

Chen, L., \& Kang, Y.-H. (2013). Anti-inflammatory and antioxidant activities of red pepper (Capsicum annuum L.) stalk extracts: Comparison of pericarp and placenta extracts. Journal of Functional Foods, 5(4), 1724-1731. https://doi.org/10.1016/j.jff.2013.07.018

Deepa, N., Kaur, C., George, B., Singh, B., \& Kapoor, H. C. (2007). Antioxidant constituents in some sweet pepper (Capsicum annuum L.) genotypes during maturity. LWT-Food Science and Technology, 40(1), 121-129., https://doi.org/10.1016/j.lwt.2005.09.016

de Sá Mendes, N., \& de Andrade Gonçalves, É. C. B. (2020). The role of bioactive components found in peppers. Trends in Food Science \& Technology, 99, 229-243. https://doi.org/10.1016/j.tifs.2020.02.032

Dzokou, V. J., Fofe, N. L., Yaouba, A., Oyono, L. D. B., \& Tamesse, J. L. (2020). Entomofauna of sweet pepper (Capsicum annuum L.) in Menoua division, Western Cameroon. https://doi.org/10.33545/27080013.2021.v2.i1a.23

Genang, A. M., Nonga, F. N., \& Ngome, P. I. T. (2020). Evaluation Of The Economic Contribution Of Horticulture In Cameroon: An Approach Using The Vector Error Correction Model. Journal of Smart Economic Growth, 5(3), 15-35. https://doi.org/10.1080/713688306

Fai, P. B. A., Ncheuveu, N. T., Tchamba, M. N., \& Ngealekeloeh, F. (2019). Ecological risk assessment of agricultural pesticides in the highly productive Ndop flood plain in Cameroon using the PRIMET model. Environmental Science and Pollution Research, 26(24), 2488524899. https://doi.org/10.1007/s11356-019-05592-2 
The Cultivation of Sweet Pepper (Capsicum Annuum) in Foumbot Agricultural Area, West Region, Cameroon

FAOSTAT: Food and Agriculture Organization of the United Nations. Statistics Division, (2014). Retrieved on October, 2020 from http://faostat.fao.org

Fratianni, F., d'Acierno, A., Cozzolino, A., Spigno, P., Riccardi, R., Raimo, F., \& Nazzaro, F. (2020). Biochemical characterization of traditional varieties of sweet pepper (Capsicum annuum L.) of the Campania Region, Southern Italy. Antioxidants, 9(6), 556.

Fonjong, L. N., \& Gyapong, A. Y. (2020). Plantations, women, and food security in Africa: Interrogating the investment pathway towards zero hunger in Cameroon and Ghana. World Development, 138, 105293. https://doi.org/10.1016/j.worlddev.2020.105293

Galani, Y. J. H., Houbraken, M., Wumbei, A., Djeugap, J. F., Fotio, D., Gong, Y. Y., \& Spanoghe, P. (2020). Monitoring and dietary risk assessment of 81 pesticide residues in 11 local agricultural products from the 3 largest cities of Cameroon. Food Control, 118, 107416. https://doi.org/10.1016/j.foodcont.2020.107416

Guilherme, R., Reboredo, F., Guerra, M., Ressurreição, S., \& Alvarenga, N. (2020). Elemental composition and some nutritional parameters of sweet pepper from organic and conventional agriculture. Plants, 9(7), 863. https://doi.org/10.3390/plants9070863

Grajeda-Iglesias, C., Salas, E., Barouh, N., Baréa, B., Panya, A., \& Figueroa-Espinoza, M. C. (2016). Antioxidant activity of protocatechuates evaluated by DPPH, ORAC, and CAT methods. Food Chemistry, 194, 749-757. https://doi.org/10.1016/j.foodchem.2015.07.119

Guilherme, R., Reboredo, F., Guerra, M., Ressurreição, S., \& Alvarenga, N. (2020). Elemental composition and some nutritional parameters of sweet pepper from organic and conventional agriculture. Plants, 9(7), 863. https://doi.org/10.3390/plants9070863

Kaur, R., \& Kaur, K. (2020). Effect of processing on color, rheology and bioactive compounds of different sweet pepper purees. Plant Foods for Human Nutrition, 75, 369-375. https://doi.org/10.1007/s11130-020-00824-0

Houjayfa, O. M., Noubissié, E., \& Ngassoum, M. B. (2020). Mobility studies of atrazine in the soil-plant system in two cameroonian vegetables Amaranthus hybridus and Corchorus olitorius. Environmental and Sustainability Indicators, 6, 100036. https://doi.org/10.1016/j.indic.2020.100036

Jean, S., Benoit, N. M., Edouard, N. A., \& Srivastava, L. P. (2017). Pesticide applications on some vegetables cultivated and health implications in Santa, North West-Cameroon. Organization, 7, 1-9. DOI: 10.4236/as.2019.108079

Joseph, B., Esther, N., \& Clautilde, M. (2020). Inventory of the biodiversity of traditional vegetables consumed by the people of the Nyong and Kelle Division: Cameroon. GSC Biological and Pharmaceutical Sciences, 10(3), 053-068. https://doi.org/10.30574/gscbps.2020.10.3.0052

Lal, M. K., Kumar, A., Kardile, H. B., Raigond, P., Changan, S. S., Thakur, N., \& Singh, B. (2020). Biofortification of Vegetables. In Advances in agri-food biotechnology (pp. 105-129). Springer, Singapore. https://doi.org/10.1007/978-981-15-2874-3_5

Lengai, G. M., Muthomi, J. W., \& Mbega, E. R. (2020). Phytochemical activity and role of botanical pesticides in pest management for sustainable agricultural crop production. Scientific African, 7, e00239. https://doi.org/10.1016/j.sciaf.2019.e00239

Lin, T. L., Chang, H. Y., \& Chen, K. H. (2020). The pest and disease identification in the growth of sweet peppers using faster R-CNN and mask R-CNN. Journal of Internet Technology, 21(2), 605-614. DOI: 10.3966/160792642020032102027

Luning, P. A., de Rijk, T., Wichers, H. J., \& Roozen, J. P. (1994). Gas chromatography, mass spectrometry, and sniffing port analyses of volatile compounds of fresh bell peppers (Capsicum annuum) at different ripening stages. Journal of agricultural and food chemistry, 42(4), 977-983.https://doi.org/10.1021/jf00040a027

Matthews, G., Wiles, T., \& Baleguel, P. (2003). A survey of pesticide application in Cameroon. Crop Protection, 22(5), 707-714. https://doi.org/10.1016/S0261-2194(03)00008-5

Mbangari, K. F., Fonteh, M. F., \& Fouepe, G. H. F. (2020). Role of farmers organizations (FOs) in the strengthening of the technical and organizational capacities of farmers in Mezam Division of the North West Region of Cameroon. African Journal of Agricultural Research, 16(5), 585-599. https://doi.org/10.5897/AJAR2019.14613

Mfopou, Y. C. M., Traore, M., Kenmogne, P. P. N., Aboubakar, A., Manguele, G. S. F., Maboune, S. A. T., \& Nacro, H. B. (2017). Structure of Vegetables Farming and Farmer's Perception of Soil and Water Degradation in Two Periurban Areas in Yaounde Cameroon. Open Journal of Soil Science, 7(11), 333. https://doi.org/10.4236/ojss.2017.711024

Nguemo, C. C., Tita, M., \& Abdel-Wahhab, M. A. (2019). Preliminary screening of pesticides used by farmers in North West Cameroon. International Journal of Halal Research, 1(1), 48-55. https://doi.org/10.18517/ijhr.1.1.48-55.2019

Njume, C. A., Ngosong, C., Krah, C. Y., \& Mardjan, S. (2020, July). Tomato food value chain: managing postharvest losses in Cameroon. In IOP Conference Series: Earth and Environmental Science (Vol. 542, No. 1, p. 012021). IOP Publishing. doi:10.1088/1755$1315 / 542 / 1 / 012021$

Tata, P. I., Afari-Sefa, V., Ntsomboh-Ntsefong, G., Ngome, A. F., Okolle, N. J., \& Billa, S. F. (2016). Policy and institutional frameworks impacting on vegetable seed production and distribution systems in Cameroon. Journal of Crop Improvement, 30(2), 196-216.

https://doi.org/10.1080/15427528.2016.1141134

Pouokam, G. B., Lemnyuy Album, W., Ndikontar, A. S., \& Sidatt, M. E. H. (2017). A pilot study in Cameroon to understand safe uses of pesticides in agriculture, risk factors for farmers' exposure and management of accidental cases. Toxics, 5(4), 30. https://doi.org/10.3390/toxics5040030

Guilherme, R., Reboredo, F., Guerra, M., Ressurreição, S., \& Alvarenga, N. (2020). Elemental composition and some nutritional parameters of sweet pepper from organic and conventional agriculture. Plants, 9(7), 863. https://doi.org/10.3390/plants9070863

Sonchieu, J., Akono, E. N., Ngwamitang, C. T., \& Ngassoum, B. M. (2018). Heath risk among pesticide sellers in Bamenda (Cameroon) and peripheral areas. Environmental Science and Pollution Research, 25(10), 9454-9460. https://doi.org/10.1007/s11356-018-1243-8.

Segnou, J., Akoa, A., Youmbi, E., \& Njoya, J. (2012). Variabilite des caracteres morphologiques et analyse des composantes du rendement chez le piment (Capsicum annuum L.). Agronomie Africaine, 24(3).

Sonchieu, J., Akono, E. N., Ngwamitang, C. T., \& Ngassoum, B. M. (2018). Heath risk among pesticide sellers in Bamenda (Cameroon) and peripheral areas. Environmental Science and Pollution Research, 25(10), 9454-9460. https://doi.org/10.1007/s11356-018-1243-8.

Siri, B.N., Nchanji, E.B. and Tchouamo, I.R. (2020) A Gender Analysis on the Participation and Choice of Improved and Local Haricot Bean (Pha-seolus vulgaris L.) by Farmers in Cameroon. Agricultural Sciences, 11, 1199-1216. https://doi.org/10.4236/as.2020.1112079

Sreeramulu, D., \& Raghunath, M. (2010). Antioxidant activity and phenolic content of roots, tubers and vegetables commonly consumed in India. Food Research International, 43(4), 1017-1020. https://doi.org/10.1016/j.foodres.2010.01.009 
Tabashnik, B. E., Mota-Sanchez, D., Whalon, M. E., Hollingworth, R. M., \& Carrière, Y. (2014). Defining terms for proactive management of resistance to Bt crops and pesticides. Journal of economic entomology, 107(2), 496-507. https://doi.org/10.1603/EC13458

Tarla, D. N., Manu, I. N., Tamedjouong, Z. T., Kamga, A., \& Fontem, D. A. (2015). Plight of pesticide applicators in Cameroon: case of tomato (Lycopersiconesculentum Mill). Farmers in Foumbot. J. Agric. Environ. Sci, 4(2), 87-98 http://dx.doi.org/10.15640/jaes.v4n2a10

Tabe-Ojong Jr, M. P., \& Molua, E. L. (2017). Technical efficiency of smallholder tomato production in semi-urban farms in Cameroon: A stochastic frontier production approach. J. Mgmt. \& Sustainability, 7, 27. doi: 10.11648/j.ajaf.20170504.15

Tandi, T. E., Wook, C. J., Shendeh, T. T., Eko, E. A., \& Afoh, C. O. (2014). Small-scale tomato cultivators' perception on pesticides usage and practices in Buea Cameroon. Health, 6(21), 2945. https://doi.org/10.4236/health.2014.621333

Tata, P. I., Afari-Sefa, V., Ntsomboh-Ntsefong, G., Ngome, A. F., Okolle, N. J., \& Billa, S. F. (2016). Policy and institutional frameworks impacting on vegetable seed production and distribution systems in Cameroon. Journal of Crop Improvement, 30(2), 196-216. https://doi.org/10.1080/15427528.2016.1141134

Zhuang, Y., Chen, L., Sun, L., \& Cao, J. (2012). Bioactive characteristics and antioxidant activities of nine peppers. Journal of functional foods, 4(1), 331-338. https://doi.org/10.1016/j.jff.2012.01.00

Publish your research article in AIJR journals-

$\checkmark$ Online Submission and Tracking

$\checkmark$ Peer-Reviewed

$\checkmark \quad$ Rapid decision

$\checkmark \quad$ Immediate Publication after acceptance

$\checkmark$ Articles freely available online

$\checkmark \quad$ Retain full copyright of your article.

Submit your article at journals.aijr.org
Publish your books with AIJR publisher-

$\checkmark \quad$ Publish with ISBN and DOI.

$\checkmark$ Publish Thesis/Dissertation as Monograph.

$\checkmark$ Publish Book Monograph.

$\checkmark$ Publish Edited Volume/ Book.

$\checkmark \quad$ Publish Conference Proceedings

$\checkmark \quad$ Retain full copyright of your books.

Submit your manuscript at books.aijr.org 